\title{
PENERAPAN SANKSI ADMINISTRATIF DALAM PUTUSAN PERKARA TATA USAHA NEGARA DI PENGADILAN TATA USAHA NEGARA SEMARANG
}

\author{
Ladju Kusmawardi1, Suteki², Aprista Ristyawati3 \\ Program Studi Magister IImu Hukum \\ Fakultas Hukum Universitas Diponegoro \\ J I. Imam Bardjo, S.H. No. 1-3, Kampus Pleburan, Semarang 50241 \\ ladjukusma17@gmail.com
}

\begin{abstract}
In carrying out its duties and authorities, the State Administrative Court (PTUN) in Indonesia is perceived as not meeting the expectations of justice seekers. This journal discusses the application of administrative sanctions, the obstacles it faces and the concept of implementing administrative sanctions in effective TUN case decisions at Semarang Administrative Court. His research method is socio legal. The results of his research were first, the application of administrative sanctions in the decision of the case of TUN in Semarang Administrative Court was not optimal. Secondly, the constraints are the low level of awareness of Government Officials, lack of active participation from Defendants and lack of supervision, the absence of specific budget regulations. Third, the concept of its application is effective, namely the existence of a legal basis for the Administrative Court to include administrative sanctions in the ruling, revise the relevant Article Provisions, there needs to be a clear commitment from the TUN Agency or Official and his superior, the need for supervision.
\end{abstract}

Keywords : Semarang State Administrative Court; Administrative Sanctions.

\section{ABSTRAK}

Dalam melaksanakan tugas dan wewenangnya, Pengadilan Tata Usaha Negara (PTUN) di Indonesia dirasakan belum memenuhi harapan masyarakat pencari keadilan. Jurnal ini membahas penerapan sanksi administratif, kendala yang dihadapinya dan konsep penerapan sanksi administratif dalam putusan perkara TUN di PTUN Semarang yang efektif. Metode penelitiannya yaitu socio legal. Hasil penelitiannya adalah pertama, Penerapan sanksi administratif dalam putusan perkara TUN di PTUN Semarang belum optimal. Kedua, kendalanya yaitu kesadaran Pejabat TUN yang rendah, tidak adanya partisipasi aktif dari Tergugat dan kurangnya pengawasan, belum adanya peraturan mengenai anggaran khusus. Ketiga, konsep penerapannya agar efektif yaitu adanya dasar hukum bagi PTUN untuk mencantumkan sanksi administratif dalam amar putusan, merevisi Ketentuan Pasal terkait, perlu adanya komitmen yang jelas dari Badan atau Pejabat TUN beserta Atasannya, perlunya pengawasan.

Kata kunci : Pengadilan Tata Usaha Negara Semarang; Sanksi Administratif.

\footnotetext{
1 Panitera Pengganti pada Pengadilan Negeri Semarang

2 Dosen Program Studi Magister IImu Hukum Universitas Diponegoro

3 Penulis Korespondensi
} 


\section{Pendahuluan}

\section{A. Latar Belakang}

Penjelasan Undang-Undang Dasar Negara Republik Indonesia 1945 telah diterangkan dan ditegaskan bahwa Indonesia adalah negara yang berdasarkan atas hukum (rechtsstaat) bukan negara yang berdasarkan atas kekuasaan belaka (machtsstaat), sehingga dapat disimpulkan bahwa segala aspek peri kehidupan berbangsa dan bernegara wajib berpedoman pada hukum yang berlaku di Indonesia ( Penjelasan Pasal 1 ayat (3) Undang-Undang Dasar Negara Republik Indonesia Tahun 1945 Perubahan Keempat).

Sehubungan negara Indonesia merupakan negara yang berdasarkan atas hukum, maka salah satu prinsip negara hukum adalah adanya jaminan penyelenggaraan kekuasaan lembaga peradilan yang merdeka, bebas dari segala campur tangan pihak kekuasaan ekstrayudisial untuk menyelenggarakan peradilan guna menegakkan ketertiban, keadilan, kebenaran dan kepastian hukum yang mampu memberikan pengayoman kepada masyarakat.

Asas kebebasan kekuasaan kehakiman dalam Undang-Undang tentang Pokok-pokok Kekuasaan Kehakiman, yaitu bebas dari campurtangan kekuasaan negara lainnya dan bebas dari paksaan, direktive atau rekomendasi dari pihak ekstra yudisial, kecuali dalam hal-hal yang diijinkan oleh undang-undang (I Gusti Ketut Ariawan, Jurnal, 2010:318).
Sehubungan hal tersebut di atas, agar pembangunan dibidang hukum dapat dikategorikan berhasil, maka harus ada jaminan kepastian hukum (law enforcement), sehingga segenap lapisan masyarakat Indonesia dapat mempercayai, menghormati dan tidak apriori terhadap proses pelaksanaan hukum di Indonesia. Pembangunan dibidang hukum jangan hanya memfokuskan pada pembuatan peraturan perundang-undangan saja (legal drafter), namun juga memperhatikan dari sisi kualitas (skill) dan mentalitas aparat penegak hukumnya (Rimdan, 2012: 5).

Pada bagian lain untuk membangun sumber daya manusia, baik dari sisi kualitas (skill) maupun mentalitas aparat penegak hukumnya memerlukan biaya yang tidak sedikit dan membutuhkan waktu yang relatif lama, namun seiring sejalan dengan pembangunan dibidang hukum, pemerintah Indonesia telah berusaha melakukan segala upaya mengadakan dan menyelenggarakan pendidikan dan latihan (diklat) serta pembinaan bagi aparat-aparat penegak hukum dan juga tidak kalah pentingnya melakukan perubahan atau penyempuraan terhadap peraturan perundang-undangan yang ada atau yang masih berlaku. (Rimdan, 2012: 10).

Pada kesempatan ini Penulis akan melakukan penelitian mengenai penerapan sanksi administratif dalam putusan perkara tata usaha 
negara di Pengadilan Tata Usaha Negara Semarang setelah perkara diputus oleh Hakim.

Peradilan Tata Usaha Negara dibentuk berdasarkan Pasal 47 Undang-Undang No.5 Tahun 1986 tentang Peradilan Tata Usaha Negara yang menyatakan bahwa pengadilan bertugas dan berwenang memeriksa, memutus, dan menyelesaikan sengketa Tata Usaha Negara (Pasal 47 Undang-Undang No.5 Tahun 1986 tentang Peradilan Tata Usaha Negara). Tujuan dibentuknya peradilan tata usaha negara adalah sebagai pengendali yuridis terhadap tindakantindakan badan/pejabat tata usaha negara, baik secara preventif maupun secara represif. Selain itu tujuan peradilan tata usaha negara adalah juga untuk memberikan perlindungan hukum bagi badan/pejabat tata usaha negara itu sendiri apabila telah bertindak benar sesuai dengan peraturan hukum yang berlaku (H. A. Muin Fahmal, 2008:290).

Pasal 17 Peraturan Pemerintah Nomor 43 Tahun 1991 jo. Pasal 5 ayat (1) Keputusan Menteri Keuangan No.1129 Tahun 1991, memang mengatur dapat dijatuhkannya sanksi administratif terhadap Badan atau Pejabat Tata Usaha Negara yang bersangkutan, tetapi penjatuhan sanksi administratif itu bersifat limitatif hanya sebatas berkaitan dengan kelalaiannya mengakibatkan negara membayar ganti kerugian. Jadi tidak ada kaitannya dengan perbuatan yang tidak mau melaksanakan putusan pengadilan yang telah mempunyai kekuatan hukum tetap (inkracht van gewijsde).

Berdasarkan hal tersebut di atas, maka Penulis tertarik untuk menulis tesis dengan judul "Penerapan Sanksi Administratif Dalam Putusan Perkara Tata Usaha Negara Di Pengadilan Tata Usaha Negara Semarang".

\section{B. Kerangka Pemikiran \\ a. Kerangka Konseptual}

Hukum sengaja diciptakan dan dibuat oleh manusia untuk diberlakukan, dilaksanakan dan ditegakkan karena tanpa hukum, kehidupan masyarakat tidak akan berjalan secara baik, masyarakat sendiri juga dibangun diatas fondasi hokum (Satjipto Rahardjo, 1980: 85).

Agar suatu permasalahan hukum dapat dilihat atau dianalisis secara mendetail maka diperlukan beberapa teori yang mendukung sehingga merupakan suatu rangkaian asumsi, konsep, model, dan definisi untuk mengembangkan, menegaskan, menekankan, menerangkan dan menjelaskan suatu gejala sosial secara sistematis dan terarah.

Prinsipnya, suatu teori merupakan hubungan antara dua variabel atau lebih yang telah diuji kebenarannya ( Soerjono Soekanto, 2001:30).

\section{b. Kerangka Teoretis}

Penelitian dalam jurnal ini menggunakan beberapa teori, antara lain yaitu, "Teori Bekerjanya hukum" yang mana menurut William 
J. Chambliss dan Robert B. Seidman bahwa menyusun suatu model mengenai bekerjanya hukum di dalam masyarakat. Setiap sistem hukum mempengaruhi, mendorong, atau memaksakan agar suatu kegiatan dilakukan oleh lembaga pembuat peraturan perundangundangan dan lembaga kekuasaan Negara (Suteki, 2013: 190-192)

Kedua, "Teori Perlindungan Hukum" yang mana memberikan pengayoman terhadap Hak Asasi Manusia (HAM) yang dirugikan orang lain dan perlindungan hukum itu diberikan kepada masyarakat agar dapat menikmati semua hak-hak yang diberikan oleh hukum.

\section{Penelitian Sebelumnya}

Penelitian sebelumnya yaitu oleh Sapta Hartana, S.H. mengenai Pelaksanaan Putusan Pengadilan Tata Usaha Negara Mengenai Ganti Rugi Dalam Sengketa Kepegawaian (Studi Kasus Putusan Nomor : 01/G/Tun/1995/ PTUN.Smg) yang kesimpulannya adalah (Sapta Hartana, S.H., Tesis, 2016) :

1. Pelaksanaan Putusan Pengadilan Tata Usaha Negara yang sudah mempunyai kekuatan hukum tetap (inkracht van gewijsde) dalam sengketa kepegawaian terhadap Putusan Nomor : 01/G/TUN/ 1995/PTUN.Smg tentang ganti rugi tersebut tidak dapat dilaksanakan dikarenakan tidak terdapatnya lembaga eksekutorial dan kekuatan memaksa dalam pelaksanaan putusan PTUN sehingga pelaksanaan putusan PTUN tergantung dari kesadaran dan inisiatif dari Pejabat TUN. walaupun telah ada didalam Pasal 116 UU No.51 Tahun 2009 Tentang Peradilan Tata Usaha Negara, namun belum ada peraturan pelaksanaannya sehingga dapat disimpulkan bahwa sanksi penerapan uang paksa dalam putusan tersebut belum terlaksana secara efektif.

2. Hambatan Pelaksanaan Putusan Pengadilan Tata Usaha Negara yang telah mempunyai kekuatan hukum tetap (inkracht van gewijsde) dalam sengketa kepegawaian terhadap putusan Nomor : 01/G/TUN/1995/ PTUN.Smg tentang ganti rugi, meliputi :

a) belum adanya ketentuan atau peraturan tentang pelaksanaan uang paksa di Pengadilan Tata Usaha Negara

b) tidak adanya partisipasi aktif dari Tergugat dan kurangnya pengawasan pelaksanaan putusan oleh Pengadilan Tata Usaha Negara

c) ketiadaan peraturan dan anggaran khusus bagi pelaksanaan upaya paksa

3. Solusi dalam menghadapi hambatan terhadap Pelaksanaan Putusan Pengadilan Tata Usaha Negara Mengenai Ganti Rugi Dalam sengketa kepegawaian terhadap putusan Nomor: 01/G/ TUN/1995/PTUN.Smg, meliputi :

a. Perlunya komitmen yang jelas dari Badan atau Pejabat TUN untuk melaksanakan 
suatu putusan Pengadilan TUN yang telah berkekuatan hukum tetap.

b. Perlunya pengawasan pelaksana an putusan pengadilan TUN

c. Perlunya anggaran Khusus

Selain itu, penelitian sebelumnya juga dilakukan oleh M. Herry Indrawan P., S.Sos, SH mengenai Pemberian Sanksi Administrasi Disiplin Pegawai Negeri Sipil di Pengadilan Tata Usaha Negara Bandung sebagai Upaya Pembentukan Aparatur yang bersih dan berwibawa, kesimpulan yang dapat diambil adalah (M. Herry Indrawan $P$, Tesis, 2008) :

1. Proses pemberian sanksi administrasi disiplin Pegawai Negeri Sipil di Pengadilan Tata Usaha Negara Bandung.

2. Kendala dalam pemberian sanksi administrasi disiplin Pegawai Negeri Sipil di Pengadilan Tata Usaha Negara Bandung .

3. Dampak pemberian sanksi administrasi terhadap kedisiplinan Pegawai Negeri Sipil di Pengadilan Tata Usaha Negara Bandung.

\section{Permasalahan}

Berdasarkan latar belakang di atas, maka yang menjadi pokok permasalahan, yakni sebagai berikut :

1. Bagaimana Penerapan Sanksi Administratif Dalam Putusan Perkara Tata Usaha Negara Di Pengadilan Tata Usaha Negara Semarang ?

2. Apa saja kendala yang dihadapi sehubungan Penerapan Sanksi Administratif Dalam
Putusan Perkara Tata Usaha Negara Di Pengadilan Tata Usaha Negara Semarang ?

3. Bagaimana konsep/model Penerapan Sanksi Administratif Dalam Putusan Perkara Tata Usaha Negara yang efektif sehingga menjamin kepastian hukum bagi pihak Penggugat?

\section{Metode Penelitian}

Suatu penelitian untuk memenuhi syarat sebagai karya ilmiah diperlukan metode penelitian atau metodologi penelitian. Secara lebih luas lagi Sugiyono menjelaskan bahwa metode penelitian adalah cara-cara ilmiah untuk mendapatkan data yang valid, dengan tujuan dapat ditemukan, dikembangkan dan dibuktikan, suatu pengetahuan tertentu sehingga pada gilirannya dapat digunakan untuk memahami, memecahkan, dan mengantisipasi masalah (Sugiyono, 2009: 6).

\section{a. Metode Pendekatan}

Penulis dalam penelitian ini menggunakan metode socio legal. Dalam socio legal mencerminkan keterkaitan antar konteks dimana hukum berada.

Teori ilmu hukum secara umum dapat diartikan sebagai ilmu atau disiplin ilmu hukum yang dalam perspektif interdisipliner dan eksternal secara kritis menganalisis berbagai aspek gejala hukum, baik sendiri maupun dalam kaitan keseluruhan, baik dalam konsepsi teoretisnya maupun dalam implementasinya, dengan tujuan untuk memperoleh pemahaman yang lebih baik dan memberikan penjelasan tentang bahan 
hukum yang tersaji dan kegiatan yuridis dalam kenyataan di masyarakat (Alimuddin, Aplikasi Pembaharuan Hukum dalam Teori Sosio Legal Studies, Ditjen Badan Peradilan, www.badilag.net, diakses pada tanggal 1 Januari 2018 pukul 20.00 WIB).

Kajian sosio legal sebagai kajian hukum interdisipliner dilakukan dengan cara mengaplikasikan perspektif keilmuan sosial terhadap studi hukum, termasuk diantaranya sosiologi hukum, antropologi hukum, sejarah hukum, psikologi dan hukum, studi ilmu politik peradilan, dan ilmu perbandingan, dengan mengupas dan menuntaskan terlebih dahulu soal kerangka normatif suatu masalah, karena praktis untuk memahami situasi kompleksnya maka studi normatif dilakukan terlebih dahulu, kemudian dibahas mengenai teks-teks, norma,dan kerjakerja doktrinal hukum yang selanjutnya studi dengan pendekatan doktrinal itu apakah dirasakan memberikan kepuasan, terutama menjawab konteks keadilan yang lebih substantif dan lebih diterima oleh publik (PPSL - EPISTEMA - AFH, Journal Term Of Reference, 2014).

\section{b. Spesifikasi Penelitian}

Spesifikasi yang digunakan dalam penelitian ini adalah deskriptif analitis, yakni suatu penelitian yang berusaha menggambarkan dan menguraikan keadaan maupun fakta yang ada di lapangan secara rinci, yang berkaitan dengan "Penerapan Sanksi Administratif Dalam Putusan
Perkara Tata Usaha Negara Di Pengadilan Tata Usaha Negara Semarang".

\section{Hasil Penelitian dan Pembahasan}

1. Menurut Eko Yulianto, Sofyan Iskandar dan Sarjoko, ketiganya Hakim pada Pengadilan Tata Usaha Negara Semarang, menerangkan bahwa penerapan sanksi administratif dalam putusan perkara tata usaha negara di Pengadilan Tata Usaha Negara Semarang belum dapat dilaksanakan secara maksimal/ optimal karena belum adanya perangkat perundang-undangan mengenai Peradilan Tata Usaha Negara yang bersifat memaksa terhadap badan/pejabat tata usaha negara untuk melaksanakan putusan yang telah berkekuatan hukum tetap (inkracht van gewijsde) tersebut, sehingga pelaksanaan amar putusan terkesan mandul, maka berdasar Pasal 116 Undang-Undang Nomor 51 Tahun 2009 tentang Perubahan Kedua Atas Undang-Undang Nomor 5 Tahun 1986 tentang Peradilan Tata Usaha Negara, Ketua Pengadilan Tata Usaha Negara dapat mengajukan permohonan tertulis kepada Presiden selaku Kepala Pemerintahan Tertinggi untuk memberikan tekanan (presure) kepada pihak Tergugat agar melaksanakan putusan yang telah berkekuatan hukum tetap (inkracht van gewijsde) (Eko Yulianto, Sofyan Iskandar, Sarjoko, wawancara pribadi, ketiganya Hakim Pengadilan Tata Usaha 
Negara Semarang, dilaksanakan masingmasing pada tanggal 8 Februari 2018 pukul 10.15 WIB, pukul 10.45 WIB dan pukul 11.15 WIB).

2. Kendala yang dihadapi sehubungan Penerapan Sanksi Administratif dalam Putusan Perkara Tata Usaha Negara di Pengadilan Tata Usaha Negara Semarang adalah sebagai berikut : (Eko Yulianto, Sofyan Iskandar, Sarjoko, wawancara pribadi, ketiganya Hakim Pengadilan Tata Usaha Negara Semarang, dilaksanakan masingmasing pada tanggal 8 Februari 2018 pukul 10.15 WIB, pukul 10.45 WIB dan pukul 11.15 WIB).

a. Masih rendahnya kesadaran Para Pejabat Tata Usaha Negara dalam melaksanakan putusan yang berkekuatan hukum tetap.

b. Tidak adanya partisipasi aktif dari Tergugat dan kurangnya pengawasan terhadap pelaksanaan putusan Pengadilan Tata Usaha Negara Semarang yang berkekuatan hukum tetap.

Dengan demikian pelaksanaan putusan menjadi tidak efektif sama sekali walaupun dalam undang-undang dijelaskan bahwa pelanggarnya dapat dibebankan upaya paksa jika putusan tersebut tidak dilaksanakan (Delfina
Gusman, Jurnal, 2010:225).

c. Belum adanya peraturan perundangundangan mengenai Peradilan TUN dan anggaran khusus dalam pelaksanaan sanksi administratif di Pengadilan Tata Usaha Negara Semarang.

3. Konsep/model Penerapan Sanksi Administratif dalam Putusan Perkara Tata Usaha Negara yang efektif sehingga menjamin kepastian hukum bagi pihak Penggugat, menurut pendapat Eko Yulianto, Sofyan Iskandar dan Sarjoko adalah

a. Adanya dasar hukum bagi Pengadilan Tata Usaha Negara untuk mencantumkan sanksi administratif dalam amar putusan.

Agar fungsi peradilan dan fungsi pengawasan oleh PTUN dapat sesuai dengan Undang-Undang Administrasi Pemerintahan, perlu disusun undangundang baru mengenai PTUN. Upaya harmonisasi tersebut perlu dilaksanakan, untuk memberi kepastian hukum bagi masyarakat (Aju Putrijanti, Lapon T.Leonard dan Kartika Widya Utama, Jurnal, 2017:274).

b. Merevisi Ketentuan Pasal 116 ayat 4 Undang-Undang Nomor 51 Tahun 2009 Tentang Perubahan Kedua Atas UndangUndang Nomor 5 Tahun 1986 Tentang Peradilan Tata Usaha Negara.

c. Perlu adanya komitmen yang jelas dari 
Badan atau Pejabat Tata Usaha Negara beserta Atasan Badan atau Pejabat Tata Usaha Negara dalam proses putusan Pengadilan Tata Usaha Negara yang telah berkekuatan hukum tetap.

d. Perlunya pengawasan pelaksanaan putusan Pengadilan Tata Usaha Negara dengan memberi batasan tenggang waktu bagi Tergugat untuk melaksanakan isi Putusan yang berkekuatan hukum tetap setelah dilakukan pemanggilan oleh Ketua Pengadilan Tata Usaha Negara.

\section{PENUTUP}

\section{A. Kesimpulan}

Berdasarkan hasil penelitian dan pembahasan sebagaimana diuraikan tersebut di atas, maka Penulis dapat memberikan kesimpulan sebagai berikut :

1. Penerapan sanksi administratif dalam putusan perkara Tata Usaha Negara di Pengadilan Tata Usaha Negara Semarang belum dapat dilaksanakan secara maksimal/ optimal karena belum adanya perangkat perundang-undangan mengenai Peradilan Tata Usaha Negara yang bersifat memaksa terhadap badan/pejabat tata usaha negara untuk melaksanakan putusan tata usaha negara yang telah berkekuatan hukum tetap (inkracht van gewijsde).

2. Kendala yang dihadapi sehubungan penerapan sanksi administratif dalam Putusan Perkara Tata Usaha Negara di Pengadilan
Tata Usaha Negara Semarang, yaitu :

2.1. Masih rendahnya kesadaran Para Pejabat Tata Usaha Negara dalam melaksanakan putusan yang berkekuatan hukum tetap.

2.2. Tidak adanya partisipasi aktif dari Tergugat dan kurangnya pengawasan terhadap pelaksanaan putusan Pengadilan Tata Usaha Negara Semarang yang berkekuatan hukum tetap.

2.3. Belum adanya peraturan perundangundangan dan anggaran khusus dalam melaksanakan putusan sanksi administratif di Pengadilan Tata Usaha Negara Semarang.

3. Konsep/model Penerapan Sanksi Administratif Dalam Putusan Perkara Tata Usaha Negara yang efektif sehingga menjamin kepastian hukum bagi pihak Penggugat, yaitu sebagai berikut:

3.1. Adanya dasar hukum bagi Pengadilan Tata Usaha Negara untuk mencantumkan sanksi administratif dalam amar putusan.

3.2. Merevisi Ketentuan Pasal 116 ayat 4 Undang-Undang Nomor 51 Tahun 2009 Tentang Perubahan Kedua Atas UndangUndang Nomor 5 Tahun 1986 Tentang Peradilan Tata Usaha Negara.

3.3. Perlu adanya komitmen yang jelas dari Badan atau Pejabat Tata Usaha Negara beserta Atasan Badan atau Pejabat Tata Usaha Negara dalam proses putusan Pengadilan Tata Usaha Negara yang telah 
berkekuatan hukum tetap.

3.4. Perlunya pengawasan pelaksana- an putusan Pengadilan Tata Usaha Negara dengan memberi batasan tenggang waktu bagi Tergugat untuk melaksanakan isi Putusan yang berkekuatan hukum tetap setelah dilakukan pemanggilan oleh Ketua Pengadilan Tata Usaha Negara.

\section{B. Saran}

1. Badan/Pejabat Tata Usaha Negara yang berkaitan dengan pelaksanaan putusan Pengadilan Tata Usaha Negara yang telah berkekuatan hukum tetap (inkracht van gewijsde) sebaiknya secara sukarela melaksanakan putusan yang telah berkekuatan tetap tersebut untuk menjamin kepastian hukum.

2. Untuk menjamin kepastian hukum (law enforcement) agar pelaksanaan putusan Tata Usaha Negara yang telah berkekuatan hukum tetap (inkracht van gewijsde) dilaksanakan oleh Pejabat Tata Usaha Negara, maka diperlukan hal-hal sebagai berikut :

a. Diperlukan dasar hukum bagi Pengadilan Tata Usaha Negara untuk mencantum- kan sanksi administratif dalam amar putusan.

b. Peraturan perundang- undangan mengenai Peradilan Tata Usaha Negara menentukan jenis-jenis sanksi administratif yang dapat dikenakan dan tata cara penerapan sanksi admnistratif tersebut.

C. Pada saat ada permohonan pelaksanaan isi putusan yang telah berkekuatan hukum tetap (inkracht van gewijsde) yang diajukan oleh Penggugat kepada Ketua Pengadilan Tata Usaha Negara sebaiknya Ketua Pengadilan Tata Usaha Negara juga memanggil Atasan Badan atau Pejabat Tata Usaha Negara yang bewenang untuk menjatuhkan sanksi administratif agar apabila Tergugat (Badan/Pejabat Tata Usaha Negara) tidak melaksanakan isi putusan, maka Atasan Pejabat Tata Usaha Negara yang berwenang dapat menghukum dengan menjatuhkan sanksi administratif.

d. Adanya batasan tenggang waktu bagi Tergugat (Badan/Pejabat Tata Usaha Negara) untuk melaksana- kan isi putusan tata usaha negara yang telah berkekuatan hukum tetap (inkracht van gewijsde) setelah dilakukan pemanggilan oleh Ketua Pengadilan Tata Usaha Negara.

\section{DAFTAR PUSTAKA}

\section{Buku}

Fahmal, H. A. Muin. (2008). Peran Asas-asas Umum Pemerintahan Yang Layak Dalam 
Mewujudkan Pemerintahan Yang Bersih. Ariawan, I Gusti Ketut. (2010). Penerobosan

Yogyakarta : Penerbit Kreasi Total Media.

Rahardjo, S. (1980). Hukum dan Masyarakat.

Bandung : Angkasa.

Rimdan. (2012). Kekuasaan Kehakiman Pasca

Amandemen Konstitusi. Jakarta : Kencana

Pramdena Grup.

Soekanto, S. (2001). Sosiologi Suatu Pengantar.

Jakarta : Raja Gravindo Persada.

Sugiyono. (2009). Metode Penelitian Pendidikan:

Pendekatan Kuantitatif, Kualitatif dan R\&D.

Bandung: Alfabeta.

Suteki. (2013). Hukum dan Alih Teknologi : Suatu

Tinjauan Sosiologis. Jogjakarta : Thafa Media.

\section{Perundang-undangan}

Undang Undang Dasar Negara Republik

Indonesia Tahun 1945.

Undang-Undang Nomor 5 Tahun 1986 tentang

Peradilan Tata Usaha Negara.

Undang-Undang Nomor 51 Tahun 2009 tentang

Perubahan Kedua Atas Undang-Undang

Nomor 5 Tahun 1986 tentang Peradilan

Tata Usaha Negara.

\section{\urnal dan Seminar}

Putrijanti, Aju., Leonard, Lapon T., dan Utama, Kartika Widya. (2017). Model Fungsi Pengawasan Oleh Pengadilan Tata Usaha Negara Sebagai Upaya Menuju Tata Kelola Pemerintahan yang Baik. J urnal MIMBAR HUKUM,Vol.29 (No.2, J uni 2017), p. 274.
Terhadap Batas-batas Kebebasan

Kekuasan Kehakiman. Masalah-masalah Hukum, Jilid 39 (No.4, Desember 2010), p.318.

Gusman, Delfina. (2010). Efektifitas Pelaksanaan Upaya Paksa Putusan Pengadilan Tata Usaha yang Telah Berkekuatan Hukum Tetap. Masalah-masalah Hukum, Jilid 39 (No.3. September 2010), p . 225.

Tesis

Hartana, Sapta. (2016). Pelaksanaan Putusan Pengadilan Tata Usaha Negara Mengenai Ganti Rugi Dalam Sengketa Kepegawaian (Studi Kasus Putusan Nomor : 01/G/Tun/1995/ PTUN.Smg). Universitas 17 Agustus 1945 Semarang. Indrawan P, M. Herry. (2008). Pemberian Sanksi Administrasi Disiplin Pegawai Negeri Sipil di Pengadilan Tata Usaha Negara Bandung sebagai Upaya Pembentukan Aparatur yang bersih dan berwibawa. Universitas Diponegoro Semarang.

\section{Internet}

Alimuddin, Aplikasi Pembaharuan Hukum dalam Teori Sosio Legal Studies, Ditjen Badan Peradilan, Retrieved from www.badilag.net, diakses pada tanggal 1 Januari 2018 pukul 20.00 WIB.

\section{Wawancara}

Eko Yulianto, Hakim Pengadilan Tata Usaha 
Negara Semarang

Sofyan Iskandar, Hakim Pengadilan Tata Usaha

Negara Semarang,

Sarjoko, Hakim Pengadilan Tata Usaha Negara

Semarang,

Mamik Hermindjaja, Panitera Pengadilan Tata

Usaha Negara Semarang 